\title{
Configurações
}

Revista de sociologia

$25 \mid 2020$

Debater o desenvolvimento: questões, dilemas e alternativas

\section{Reprodução colonial capitalista e resistências indígenas: estudo comparativo entre Brasil e México}

Capitalist colonial reproduction and indigenous resistance: a comparative study between Brazil and Mexico

Reproduction coloniale capitaliste et résistances indigènes : étude comparative entre le Brésil et le Mexique

Clayton Emanuel Rodrigues e Cleildes Marques de Santana

\section{(2) OpenEdition}

Journals

Edição electrónica

URL: http://journals.openedition.org/configuracoes/8821

DOI: $10.4000 /$ configuracoes. 8821

ISSN: 2182-7419

\section{Editora}

Centro de Investigação em Ciências Sociais

\section{Edição impressa}

Paginação: 112-127

ISSN: 1646-5075

\section{Refêrencia eletrónica}

Clayton Emanuel Rodrigues e Cleildes Marques de Santana, « Reprodução colonial capitalista e resistências indígenas: estudo comparativo entre Brasil e México ", Configurações [Online], 25 | 2020, posto online no dia 23 junho 2020, consultado o 25 junho 2020. URL : http://journals.openedition.org/ configuracoes/8821; DOI : https://doi.org/10.4000/configuracoes.8821 
Rodrigues, Clayton Emanuel; Santana, Cleildes Marques de -Reprodução colonial capitalista e resistências indígenas: estudo comparativo entre Brasil e México. Configurações, vol. 25, 2020, pp. 112-127.

\title{
Reprodução colonial capitalista e resistências indígenas: estudo comparativo entre Brasil e México
}

\author{
CLAYTON EMANUEL RODRIGUES * \\ Universidade Federal do Oeste da Bahia \\ CLEILDES MARQUES DE SANTANA ** \\ Universidade Federal do Oeste da Bahia
}

\begin{abstract}
Resumo
A partir estudos comparativos de documentos histórico-sociológicos das lutas anticoloniais no Brasil e no México, interseccionado com as pesquisas etnográficas realizadas em Chiapas-MEX, analisamos as consequências das lutas anticoloniais entre os nativos. A violência do desenvolvimento capitalista como prática governamental racializada, implicou epistemicídios, necropolíticas, cujo biopoder invisibiliza e infantiliza os povos nativos e suas formas alternas de existência e autogoverno, cujas resistências político-econômicas contrapõem-se ao desenvolvimento capitalista. Concluímos que o crescimento de resistências nativas no sec. XX, refazem as narrativas históricas e indicam mudanças no cenário político-social da América Latina nos próximos anos.
\end{abstract}

Palavras-chave: Decolonialismo, capitalismo periférico, povos originários, desenvolvimento, violência.

\footnotetext{
Abstract

Capitalist colonial reproduction and indigenous resistance: a comparative study between Brazil and Mexico

Based on comparative studies of historical-sociological documents of anti-colonial struggles in Brazil and Mexico, intersected with ethnographic research conducted in Chiapas-MEX, we analysed the consequences of anti-colonial struggles among natives. The violence of capitalist development as a racialised governmental practice has implied epistemicides, necropolitics, whose biopower makes invisible and infantilises the native peoples and their alternate forms of existence and self-government, whose political-economic

* Doutorando do ICS, universidade do Minho. E-mail: pretomisturado@gmail.com

** E-mail: cleildes.ssa@gmail.com
} 
resistances oppose capitalist development. We conclude that the growth of native resistances in the twentieth century redoes the historical narratives and indicates changes in the political-social scenario of Latin America in the coming years.

Keywords: Decolonialism, peripheral capitalism, natives, development, violence.

Résumé

Reproduction coloniale capitaliste et résistances indigènes : étude comparative entre le Brésil et le Mexique

À partir d'études comparatives de documents historico-sociologiques des luttes anticoloniales au Brésil et au Mexique, croisées avec les recherches ethnographiques menées au Chiapas-MEX, nous avons analysé les conséquences des luttes anticoloniales entre les indigènes. La violence du développement capitaliste en tant que pratique gouvernementale racialisée a impliqué une dimension épistémique, nécropolitique, dont le biopouvoir rend invisible et infantilise les peuples indigènes et leurs formes alternatives d'existence et d'autonomie dont les résistances politico-économiques s'opposent au développement capitaliste. Nous concluons que la croissance des résistances indigènes au XXe siècle refait les récits historiques et indique des changements dans le scénario politico-social de l'Amérique latine dans les années à venir.

Mots-clés: Décolonialisme, capitalisme périphérique, peuples autochtones, développement, violence.

\section{Introdução}

A partir de estudo teórico-documental, histórico e sociológico, comparativo entre Brasil e México, interseccionados com nossa pesquisa de campo etnográfica exploratória, nomeadamente as realizadas junto às reuniões da Universidad de la Tierra, CIDECl, em San Cristobal de las Casas, Chiapas - MEX, produzimos algumas formulações sobre as resistências nativas e as guerras coloniais capitalistas. $O$ que detidamente nos interessa são os choques entre capital e tipos de produçao nativas. Dois fatos aqui são contrapostos: 1 - as formas de produção da existência antes da invasão colonial, parcialmente ainda existentes; 2 - os conflitos causados pela força externa que representou a invasão colonial e seus modos de produção da vida, impostos sob violência aos nativos. Para tanto, discutiremos, se bem que de forma não extensiva, a racialização e a consequente luta colonial contra os povos originários e africanos escravizados nesses países, bem como a imposição de determinado tipo de "progresso" e "desenvolvimento" capitalistas, a definir o atual quadro das lutas sociais. Valendo-nos dos acontecimentos significativos que conflitaram substancialmente os modos de vida, produção e consumo desses povos nativos, analisamos como a luta pelo desenvolvimento econômico colonial 
foi acompanhada de epistemicídio, da necropolítica, de racialização dos povos e destruição da natureza.

\section{Dos povos nativos}

Os territórios "americanos" não eram desabitados quando aportaram Espanha e Portugal por estas bandas. De fato, as populações nativas, particularmente da "mesoamerica", possuíam uma história social e econômica própria, conforme refere Carrasco,

"a zona mesoamericana foi a que atrasou a conquista e a colonização espanhola e, portanto, constitui o antecedente indígena primordial para a formação da nacionalidade mexicana. Estava povoada por sociedades que, mediante um longo processo de desenvolvimento, haviam alcançado desde uns dois mil anos antes da Conquista o nível chamado geralmente de civilização, quer dizer, um tipo de cultura caracterizado por um sistema de produção com cultivos intensivos e artesanatos desenvolvidos, capaz de manter uma população numerosa em que existia uma divisão de trabalho que incluía a distinção entre cidade e campo, entre um grupo de trabalhadores dedicados principalmente à produção de bens materiais e outros dedicados à distribuição e ao governo" (Carrasco, 2013: 155).

Dá-se conta da existência de populações entre trinta mil e onze mil anos atrás, respectivamente, em México e Brasil (Lorenzo, 2013). As caracterizações das economias no México vão desde estamental, oriental, mercantil à comunal. Ora a terra pertence a deuses ora à organização política, ora a terra pertence à comunidade ora pessoas e comunidades pertencem à terra. Igualmente foi na organização política: democracia, reinado, teocracia, comunitarismo. Não há acordo entre os investigadores sobre as caracterizações políticas e socioeconômicas antigas, senão de constituírem-se sob a forma urbana-campesina (Carrasco; Bernal; Martinez; Lira y Muro, 2017; Todorov, 1993). A organização urbana nativa favoreceu a resistência militar à colonização na mesoamérica. Todavia, derrotados, entrincheiravam-se nos vãos das montanhas e lá constituíam outras cidades, mais protegidas dos colonizadores. Nesse início do sec. XXI, permanece a rica diversidade entre povos descendentes de Maias, Astecas, Zapotecas, Olmecas, entre outros, apesar da invisibilidade nacional.

Quanto ao Brasil, Bethell (1990) define os povos originários brasileiros em três grandes troncos linguísticos: tupi, aruak e caribe. Em geral, os povos viviam semi aldeados e sua economia incluía agricultura, caça, pesca, fabricação de arcos, cerâmica, ao tempo da colonização. Seminômades, tinham grande mobilidade territorial dependente das guerras, dos meios de bens necessários à sobrevivência, clima, entre outros. Não conheciam a escrita alfabética. A maioria não tinha religião 
organizada. Viviam comunitariamente sem autoridades formais individuais, com exceção do pajé, autoridade espiritual. Os conselhos de Anciões eram a base da organização política e tinham o papel de discussão diária e resolução dos problemas e conflitos. Os Tupinambás, Tupis, Aimorés, entre outros, dividiam entre si o litoral, os dois últimos foram dizimados pelos invasores europeus. Diversamente do México, criadores de cidades, os índios brasileiros viviam na e da floresta e seu aldeamento era fugaz. Suas capacidades de enfrentamento foram enfraquecidas pelas epidemias e pela urbanização, que abriam clarões desflorestados dificultando suas táticas voltadas para a camuflagem e ataques surpresas. Os que não morreram assassinados ou doentes fugiram do aldeamento forçado e se embrenharam nas matas no interior do território, onde até hoje mantém suas formas de vida extrativas, coletoras, caçadoras e artesanais. (Ribeiro, 1995; Prado Jr., 1961; Lopes, 2017; Brasil, 1994).

O Estado brasileiro impôs-se como autoridade soberana e tutelou-os até 1988, porém, não conseguiu entrar nos territórios florestais mais afastados, cobiçados em 2020 para expansão do agronegócio e mineração'. A tática colonial para destruição dos indígenas continua a mesma hoje, o desflorestamento.

A população nativa estimada no Brasil no sec. XVI está entre um milhão e quinhentos mil a 5 milhões. Ribeiro (1995) nos dá a cifra de dois milhões de indígenas no início da invasão, reduzidos a cem mil, em 1940. O crescimento da interiorização com destruição das florestas, a catequização e a escravização, trouxeram as guerras e as doenças que empurraram os nativos brasileiros para a região Amazônica, onde tinham a proteção da selva. Algumas nações, como a Guarani e a Tupinambá, adotaram o nomadismo como forma de não localização pelos invasores (Prado Jr. 1961, Ribeiro, 1995; Fausto, 2010). Ainda assim, a população nativa foi reduzida quase na mesma proporção em que se destruiram as florestas para estabelecimentos das cidades, das minas de ouro, dos grandes latifúndios de monocultura. Os nativos são inimigos não apenas dos colonizadores e de sua civilização, mas dos tipos de progresso e do desenvolvimento capitalistas:

...índios e civilizados se defrontam e se chocam hoje em condições muito próximas em que se deram os primeiros encontros da Europa com a América indígena. De um lado, são índios armados de arco e flechas que, do recesso de suas matas, olham o brasileiro que hoje avança sobre suas terras, tal como o Tupinambá quinhentista olhava as ondas de europeus que se derramavam das naus portuguesas. De outro lado, são brasileiros engajados nas frentes de expansão da sociedade nacional, que avançam por uma terra que consideram sua e vêem no índio uma ameaça e um obstáculo. (Ribeiro, 1996:19)

1 Ao tempo da revisão desse artigo, já em 2020, Bolsonaro assina um projeto de lei que libera a mineração e o agronegócio nas terras indígenas: https://veja.abril.com.br/politica/ bolsonaro-assina-projeto-que-libera-mineracao-em-terras-indigenas/. 
Com a independência do Brasil, o desenvolvimento capitalista periférico teve na Revolução de 1930 e depois na Ditadura Militar, 1964-1985, seus grandes protagonistas. Esta última, a fim de servir aos interesses internacionais e nacionais, atacou os povos indígenas para erguer grandes projetos de desenvolvimento e integração nacional, como a Transamazônica, as hidroelétricas (Tucuruí, Xingó, Itaipu, Jirau), os empreendimentos mineradores (Serra Pelada, Carajás) (cf. SIMINERAL 2019). Como consequência, muitos povos foram exterminados, presos e torturados e suas terras entregues ao Capital. A Comissão da Verdade, querendo esclarecer os crimes dos tempos ditatoriais, fez o seguinte relato:

Atualmente, os documentos oficiais produzidos pela Comissão da Anistia, instalada em 2001 pelo Ministério da Justiça com a finalidade de analisar os requerimentos de anistia política, listam 457 vítimas dos militares, entre mortos e desaparecidos. Mas a soma dos casos que puderam ser apurados pela Comissão da Verdade registram oito mil indígenas mortos entre 1964 e 1985 e registra-se que outras mil pessoas pertencentes a organizações políticas também foram mortas.(https://avispa.org/indigenas-violacao-regime-militar/).

A partir da constituição de 1988, houve uma mudança na taxa de natalidade e a população nativa, entre 1991 e 2000, teve aumento de $150 \%$, chegando a 896 mil pessoas no Censo 2010 (IBGE, 2012)

O crescimento de $10,8 \%$ ao ano da população que se declarou indígena, no período 1991/2000, principalmente nas áreas urbanas do País, foi atípico. (...) o Censo Demográfico 1991 revelou que em 34,5\% dos municípios brasileiros residia pelo menos um indígena autodeclarado; no Censo Demográfico 2000, esse número cresceu para 63,5\%; e, segundo os dados mais recentes, do Censo Demográfico 2010, atingiu 80,5\% dos municípios brasileiros. (IBGE, 2012:4).

Nota-se no mesmo recenseamento um maior número de população nativa na região amazônica, confirmando a hipótese de que a floresta favoreceu a resistência da população nativa. Em 2016, entretanto, recrudesce a violência contra os povos indígenas, em razão dos interesses da mineração e do agronegócio por suas terras, como refere a ONU:

Os povos indígenas brasileiros enfrentam atualmente riscos mais graves do que em qualquer outro momento desde a adoção da Constituição de 1988. Essa é a conclusão de relatório que será apresentado na terça-feira (20) ao Conselho de Direitos Humanos pela relatora especial da ONU sobre os direitos dos povos indígenas (https://nacoesunidas.org/situacao-dos-povos-indigenas-no-brasil-e-a-mais-grave-desde-1988-diz-relatora-da-onu/), 
Situação que ainda vigora em 2020.

\section{Colonialidade e dependência}

A noção neocolonial universalizante de progresso capitalista, no contexto da economia-mundo ${ }^{2}$, colocam-nos muitos desafios, entre eles, a visão de linearidade histórica de que o desenvolvimento geral caminharia do primitivo para o civilizado, transforma-se rapidamente em lutas pela civilidade, segundo o entendimento europeu e em enraizadas práticas de supremacia racial. Essa ideia evolutiva tornou a presença desses povos nos territórios invadidos invisíveis para a empreitada europeia. Tal invisibilidade, cedo ou tarde, levaria a guerra colonial a se revestir de um caráter de extermínio racial, epistemológico (Santos, 2010), histórico e físico, como biopoder (Foucault, 2008) e necropolítica (Mbembe, 2011).

Se a existência real, as condições e contradições materiais de existência definem as práticas, as necessidades e as ideias, isso significa que, também pelo contrário, as ideias expressam as contradições da existência e são elas (as ideias) produtos dessa materialidade. Nesse sentido, como vemos e agimos depende de quais contradições materiais e antagonismo queremos resolver. As práticas de progresso e desenvolvimento social, tecnológico e material não são diferentes. O mundo econômico, em seus períodos e ciclos, responde às necessidades de produtos úteis numa relação circular, que se conectam por retroalimentação e mútuas dependências, escreveu Schumpeter (1997). Ocorre que as necessidades podem variar segundo um tipo de sociedade de mercado e outra de subsistência, modificando o motivo da produção ou a razão produtiva, como resposta às necessidades efetivas.

Um exemplo dessas diferenciações é a relação que muitos povos originários mantêm, ainda hoje, com a terra: em uma reunião do $\mathrm{CIDECI}$, no fim de abril de 2019, San Cristóbal de Las Casas, Chiapas-MEX, indígena Mariana, de uma comunidade aderente à Sexta Declaração Zapatista e pertencente ao Conselho Nacional Indígena, em Chiapas, chorava copiosamente porque incendiaram os bosques da "mãe terra". Expressava dolorosamente que pertencia à terra, que sofria com ela.

A noção exposta tinha um diferencial, para além da emoção que a todos atingiu. A terra não Ihe pertencia, ao contrário, Mariana pertencia à terra. Sua relação com a terra é de pertencimento, de vínculo afetivo, de vida, em oposição ao pequeno proprietário camponês, que além de dono da terra, mantém com ela uma relação de valor produtivo.

Há um sentimento e uma prática de pertencimento à terra e não ao contrário. Aos nativos, soa-lhes inimaginável uma ação ou voto individual atingir a toda 
comunidade e suas terras. Há povos cuja decisão sobre questões relativas à existência comunitária (terra) não passa pela representação estatal moderna e nem pertence ao indivíduo, assim como a terra não lhe pertence ou à comunidade. Uma comunidade, um voto, em contraste com uma cabeça, um voto; um território, uma comunidade que lhe pertence, em vez de propriedade individual da parcela ideal da terra. Se há uma votação, essas comunidades expressam o voto coletivo, e não individual, essa uma das razões da rejeição às consultas sobre grandes projetos realizadas pelo governo mexicano entre 2016-2019 (Toledo e Fraga, 2019). A democracia-mundo da revolução francesa, do voto secreto, individual e universal, não tem nenhum sentido, senão como violência à decisão comunitária. Muitos investigadores sociais dão conta dessa concepção sobre a terra entre los pueblos originarios "americanos", como também da violência que significa para eles a instituição da propriedade privada, das fincas, das fazendas e do trabalho escravo ou servil (García, 2011; Mora, 2018; Fenner, 2010; Cusicanqui, 2010).

Os capitalistas na Europa fizeram opções diante das contradições concretas existentes, segundo seus interesses. Por exemplo, a ideia matriz do mercado dirigido por uma mão invisível, que se autorregula, não valeu para organizar a sociedade politicamente. As liberdades individuais não valem para a autorregularão das relações sociais, assim, deve o monopólio do uso da força pelo Estado (Weber, 1979) substituir a mão invisível que falta à sociedade. A liberdade individual, socialmente definida, é perigosa exatamente porque pode contrariar os interesses econômicos de quem explora.

Na Europa, o capitalismo aplicado, já em seu nascimento, não demorou a namorar com as velhas oligarquias, com a igreja, latifúndios, que haviam derrubado do poder. O desenvolvimento colonial demonstra bem que a teoria aplicada na Europa, e depois nos EUA, não necessariamente deveria ser aplicado ao resto do globo. México e Brasil, objetos de nossos estudos, são guindados pela divisão internacional de trabalho a uma economia de suporte agrário-mineral e têm um desenvolvimento capitalista diverso dos centros capitalistas e são deles dependentes: "durante o período de inserção no sistema de divisão internacional do trabalho, vale dizer, na fase formativa deste, o impulso primário dinamizador das economias da periferia não tinha origem no desenvolvimento de suas próprias forças produtivas" (Furtado, 2013).

Nessa partilha desigual dos interesses do capitalismo central e periférico, cabe aos Estados modernos mexicano e brasileiro conseguir domínio político-econômico em todo território. No entanto, em razão de não lograrem pacificar os povos nativos, a tática de extermínio contra nativos e negros escravos tornou-os em Estados violentos. Tampouco lograram por completo a pacificação da população ocidentalizada, na medida em que a violência endêmica contra os pobres e negros das cidades configurou-os como "Estados partidos", para parafrasear o livro "Cidade Partida", de Ventura (1994). Nesse sentido, nem conseguiram se impor totalmente enquanto autoridade social, nem imporem a economia capitalista por 
completo e em todo lugar. A sugestão de que isso tenha relação apenas com o carácter dependente do capitalismo local, portanto sem relação com as resistências, é mais uma vez tornar invisível, infantilizar e racializar as formas alternas e as autonomias comunitárias sustentadas pelos povos originários.

De outro lado, todo sistema econômico se faz acompanhar de um sistema e regime políticos, logo, uma economia-mundo deve implicar uma democracia-mundo, em acordo com a divisão mundial de trabalho e produção, razão pela qual a ONU define a democracia e o liberalismo como formas eleitas de civilidade. A essa questão, talvez a resposta esteja na inserção do capitalismo colonial na América Latina com um sistema político gestor típico, já que a forma econômica anterior a si na Europa, o feudalismo, não teve presença nas Américas. Porém a pergunta chave é: lograram os Estados o domínio de todo território e povos para impor sua versão do capitalismo dependente?

O Estado capitalista exógeno aos povos nativos definiu-se por um Estado quase moderno, porque colonial e racializado, repressivo mais do que dominador, imprimindo uma violência seletiva contra índios, negros, e pobres, cujo alcance não se compara em quantidade e letalidade às repressões e violências cometidas contra os operários e pobres nos Estados burgueses europeus. A violência racializada praticada pelo Estado colonial tornou-se a tônica dos Estados latino-americanos pós independências, cujas composições étnica e ética constitucionais de Estado têm a lógica colonial (Stein et Barbara, 1970).

A tarefa dos Estados invasores foi submeter tais populações para servir-lhes de escravos, guias, soldados, a buscar riquezas minerais, nos primeiros cem anos (Prado Jr., 1970). Em seguida, ter domínio territorial, organizar a administração, o exército, e constituir formas de governo, a fim de facilitar a fiscalização pela coroa aos produtos da pirataria, organizar o comércio ultramarino e a exploração sistemática das novas terras (Fernandes, 1972).

A guerra colonial nutria-se moralmente do caráter civilizatório e cristão de seu empreendimento. Os cortes entre civilização e primitivos; pagãos e cristãos, serviram de mote, a fim de que as invasões tivessem suporte moral e se auto justificassem.

A noção implicada de superioridade civilizacional introduziu a racialização. Os "atrasos" técnicos e organizacionais dos povos originários tinham relação com a inferioridade da raça indígena diante do europeu. Tal inferiorização e infantilização afirmavam a inexistência da propriedade territorial e a inabilidade de autogoverno pelos povos autóctones, a possibilitar a escravização, o descarte de suas vidas e desprezo das formas econômicas existentes, logo, também a extração do que lhes fosse útil, tendo repercussão socio-estrutural no uso endêmico da violência pelos Estados modernos latino-americanos.

O papel do Estado Colonial era impor um tipo de organização comercial em acordo com as necessidades mercantis de acumulação de capital a um mundo de outro tipo. Vencida a primeira fase, com parte dos indígenas mexicanos recuando 
para o interior das montanhas ou para as florestas no Brasil, com a impossibilidade de se obter mão de obra, já que a "indolência" e resistências nativas os desqualificavam para o trabalho, principalmente no Brasil, se investiu no comércio de africanos para escravização.

As independências foram uma saída estratégica para evitar a continuidade dos confrontos. As guerrilhas, as revoltas, foram a tônica até a independência. Dirigidas pelos descendentes dos colonizadores com interesses econômicos específicos, tanto no Brasil, fixada na figura de D. Pedro I, quanto no México, em uma guerra prolongada de 1810 até 1824, acabaram por retirar o caráter invasivo da guerra colonial para produzir uma organização estatal interna ou nacional, a partir dos moldes europeus, mantendo os povos originários e negros invisíveis, na miséria ou na escravidão. Assim foi por toda a América, incluso os EUA. Mesmo Simon Bolívar já havia incorporado o pensamento liberal dos colonizadores nos processos independentistas:

Bolívar mudou de opinião acerca dos escravos, e seu companheiro de luta, San Martín, decretou em 1821 que "no futuro, os aborígenes não seriam chamados índios; são filhos e cidadãos do Peru, e serão conhecidos como peruanos". (Poderíamos adicionar: apesar do capitalismo não ter chegado, todavia, a estes analfabetos.) (Anderson, 1993. p.82).

A violência racializada praticada pelo Estado colonial será a tônica dos Estados latino-americanos pós independências.

\section{Decolonialidade e Sistema Mundo}

As primeiras teorias econômicas sobre o capitalismo dependente foram formuladas, entre outros, por Celso Furtado, que desconsiderou a presença de economias alternas em território brasileiro, porque centrou-se na presença e nas políticas do Estado, relativamente à "economia-mundo" e às economias das terras consideradas "produtivas". Isso posto, percebeu o papel da divisão mundial de trabalho destinado às economias "periféricas".

A economia política liberal, então prevalente, distribui-se pelo mundo em luta levando em conta o nível de desenvolvimento capitalista, segundo os "recursos naturais" e sociais disponíveis, as estruturas de poder, o papel do país na divisão social do trabalho e da produção a nível mundial, de antemão definidos, para decidir o que cabe a cada um, consoante o tipo de exploração a que os territórios e seus respectivos povos deveriam ser submetidos (Santos, 2015; Furtado, 2005; Frank, 1980; Prado Jr., 1970). Onde há um Estado "livre" e "soberano", há a implantação do domínio capitalista como projeto de desenvolvimento e exploração. 
Aqui cabe a ressalva que, considerado os chamados Estados soberanos reconhecidos como definidores da presença do sistema global capitalista, se desconsidera, a partir das visões colonializantes, os povos "invisibilizados" que, embora territorializados, não constituem Estados soberanos ou Nações dentro da ideia de Estado unificado.

A adoção do termo "economia-mundo" para definir a "economia mundial capitalista" tem então o sentido de considerá-la prevalente entre os Estados. "Se é verdade que o capitalismo não logrou substituir imediatamente essas economias locais ou regionais ele rompeu desde então sua virgindade e fê-las ingressar na lógica do mercado mundial", afirma Santos (2012:11).

O problema é ver as economias locais resistentes já destruídas ou inexistentes ou inseridas no sistema-mundo, quando a abstração de um sistema mundial se impõe sobre todos os outros sistemas ou excluindo-os ou incorporando-os à sua lógica. Assim a noção de capital aparece como uma noção universal, ainda que partindo das sociedades específicas onde o produto se transforma em mercadoria e a relação de troca tenha uma componente de excedente necessária, porém tal noção não é válida para todas as sociedades, senão quando se vê sociedade como sinônimo de Estado. E talvez seja exatamente isso que aconteça:

Em poucas palavras, o estudo do sistema-mundo é necessário, mas insuficiente para responder a outros interrogantes não menos importantes da realidade social, que se definem em outras unidades. Definir um único nível de análise ou de abstração implica supor que os demais não só são falsos em substância, como simples derivações do nível privilegiado. Isto assinala Wallerstein quando afirma que o sistema-mundo "teria um único tipo de unidade em lugar de unidades dentro de outras unidades" (Osório, 2017:4).

Em "As formas de produção da ignorância", Santos discute os silenciamentos impostos e diz-nos o seguinte: "as verdades que não cabem na verdade monopólica não existem e tampouco existem os povos que as subscrevem [...] foi por isso que o genocídio dos povos indígenas e o epistemicídio de seus conhecimentos, perdoe o pleonasmo, andaram de mãos dadas" (2019, s/p). Acrescentamos a invisibilidade da economia indígena encadeada com seu modo de vida, quando é analisada, nomeadamente por parte de alguns antropólogos, é-o como dom ou dádiva, enquanto economia simbólica ou "que as sociedades que estudam estiveram 'tradicionalmente' em repouso, como eles as encontraram, e imutáveis" (Frank, 1980:175), poucas vezes como sistemas econômicos dinâmicos e atuais, com suas consequentes relações de produção e reprodução material e política de existências.

Se é verdade que o Estado capitalista prevalece nas Américas, enquanto força econômica e social, ele é exógeno às populações nativas, nas quais sobrevivem 
hábitos e práticas econômicas e reprodução de relações sociais próprias (Quijano, 1992). As relações do Estado com a população indígena são conflituosas e formatadas pela pressão social que geram. Se o capitalismo se impõe nas Américas e necessita, em geral, do uso da força do Estado para impor-se, demonstra que o convívio com o domínio territorial e de riquezas por comunidades indígenas não é pacífico e nem total (Quijano, 1992). Os argumentos descaracterizadores do indígena passam pelo discurso do desaldeamento. Alguns diriam que o fato de todos usarem celulares, alguns andarem de carro, consumirem produtos industrializados, de alguma maneira indicaria que houve uma assimilação dessas comunidades às formas capitalistas. Bem, as rodas são usadas até hoje e a elas foram acrescentados avanços tecnológicos, embora sua invenção seja de passado imemorável; a bússola e o papel da China Imperial; a moeda de Ciro; o perfume egípcio, os números árabes, parte do direito romano e cristão, e, nem por isso, os capitalistas se consideram feudais, faraônicos e imperiais, ou mesmo "bárbaros". O que determina as prevalências política e econômica identificadoras não são os usos de alguns instrumentos, teorias e técnicas do passado ou presente, mas as características fundamentais que definem os sistemas enquanto tais. Apesar de a moeda existir bem antes do capitalismo, só no capitalismo ela teve o papel de equivalente geral do tempo médio socialmente gasto na produção da mercadoria (Marx, 2008). De igual modo, embora no capitalismo haja formas de escravidão, entre outras características do passado, nem por isso deixa de ser um sistema econômico baseado na "mão de obra livre". Não há dúvidas sobre a produção tecnicamente superior de bens de consumo excedentes pelo capitalismo, cuja relação econômica é prevalente entre a maioria de brasileiros e mexicanos, todavia há um custo político-social e natural que nem todas as comunidades originárias desejam pagar ou manter (Mora, 2018; SupGaleano et. al., 2015).

O desafio, portanto, é reconhecer a presença das plurinacionalidades, das pluriterritorialidades e das formas econômicas alternas dentro de vários Estados "soberanos" nas Américas, a indicar uma relação socioeconômica não subsumida pela economia-mundo, mas em disputa. Cabe lembrar que os territórios sob a soberania dos povos originários foram e são das mais importantes resistências à neocolonização liberal, ao desenvolvimento e aos parâmetros de progresso do Estado capitalista, calçados no incremento da produção e do consumo predatórios, de imposição dos megaprojetos e infraestruturas energéticas, minerais e viárias, vinculadas ao uso e destruição dos "recursos naturais" das terras ocupadas pelos povos originários e quilombolas. Terra e natureza basilares de suas formas de vida socioeconômica comunais, sem as quais desaparecem.

Há enorme fosso entre os governos do México que representam o capitalismo exógeno, da colonização à república, e os povos originários espalhados por toda sua região sul, a partir da Cidade do México, aos quais quer-se impor os modelos liberais de propriedade, indicando polos de tensão, como também antagonismos 
fundamentais entre capitalistas e comunidades nativas. Tal análise, entretanto, não nega que muitas comunidades foram, como afirma corretamente Ribeiro (2017), incorporadas ao sistema-mundo ou destruídas. Mas é premente reconhecer quando existem e os ressurgimentos. Daí o reconhecimento do sistema-mundo enquanto força exógena, com defensores internos, que pressiona desde fora os nativos resistentes à capitulação.

Nessa direção, tanto Luxemburgo (1970) quanto Schumpeter (1997), e mesmo Marx (1982), quando discutem o caráter da reprodução simples, consideram a necessidade dessa reprodução se tornar hábito regular para ter efetiva consequência tanto na produção material como imaterial da vida, formando uma cadeia, um encadeamento entre economia e relações sociais. O que está em jogo na luta colonial-imperialista contra o direito comum à terra é essa reprodução da vida, nesse encadear entre passado e presente. Ou se produz e se reproduz prevalentemente o sistema capitalista proprietário, tornando-o hábito a repetir e reproduzir as relações e formas capitalistas de produção e de existência ou se produz e reproduz prevalentemente a relação "natural" e comum com a terra e tudo o que isso significa no campo da produção material e imaterial da existência, enquanto comunidade. Vale citar Luxemburgo:

Os fins econômicos do capitalismo em luta com as sociedades de economia natural são: I - Apropriação direta de importantes fonte de forças produtivas, como a terra, a caça nas selvas virgens, os minerais, as pedras preciosas, os produtos das plantações exóticas, como a borracha etc. II - "Libertar" operários e obrigá-los a trabalhar para o capital. III- Introduzir a economia de mercado. IV - Separar a agricultura do artesanato. (Luxemburgo, 1970: 318)

De forma geral, pode-se dizer que esses instrumentos e objetivos permanecem latentes hoje, desde a colonização, o que demonstra que os objetivos do capital, depois de mais de 500 anos de presença no Brasil e México não foram suficientes para destruir as formas comunais resistentes.

\section{A violência do desenvolvimento}

O capitalimo nas Américas não é fruto de um desenvolvimento de suas forças produtivas, lhe é exógeno. Não havia base social histórica local que possa se assemeIhar à europeia para sua fundação, ou seja, uma sociedade feudal contraposta às relações mercantis (Frank, 1980).

Porquanto, para afirmar-se como civilização superior contrapos a noção de pessoa e de desenvolvimento europeus válidos e racializados contra as populações dominadas pela força. A força é utilizada como instrumento de docilização dos corpos e quebra das resistências, e as ideologias, religião, técnicas de repressão e 
racialização, noções de civilização, progresso e desenvolvimento para modificação das mentes, circulando socialmente, a partir de cima, como valores verdadeiros, consagrados, em oposição a "anomia" reinante no mundo "primitivo" infantilizado (Quijano, 1992).

Tais conceitos serão, depois, elevados à primeira categoria. No início eram meramente funcionais, utilitários, para tornarem-se, em seguida, razão não apenas da escravidão, como da noção de subdesenvolvimento capitalista, a formar uma linha histórica de desenvolvimento que coloca antiteticamente África e América Latina nos extremos opostos da divisão mundial de trabalho e produção, em acordo com a civilidade estadunidense-europeia ocidental, para, em seguida, tê-las como mundializada, ou como economia-mundo.

É nesse sentido que Senghor e Madridejos (2008) referem a tutelarização dos povos descolonizados como tática de manutenção da supremacia europeia e estadunidense sobre essas nações, e "sentenciava: os povos coloniais devem estar submetidos a uma tutela que os tornasse capazes de se autogovernar. O sistema de mandatos, consagrado pela Sociedade das Nações (organização internacional fundada em 10 de janeiro de 1920) ou o regime de tutela, implantado pelas Nações Unidas (fundada em 26 de junho de 1945), foram suas principais manifestações".(http://orientika.blogspot.pt/2008/04/teorias-sobre-o-colonialismo. html). Referem ainda a teorização alemã de "territórios sem dono" que justificaria a apropriação por reconhecimento ao "trabalho" executado pelos comerciantes e colonos anteriormente, e também, o nascimento da noção norte-americana, com a doutrina Monroe, para evitar a retomada dos territórios por países europeus, sem a sua autorização.

A colonização abriu uma fenda entre nativos, brasileiros e mexicanos integrados ao sistema-mundo capitalista no Estado moderno colonial, à maneira de Ribeiro (2017). A defesa das terras indígenas e suas formas alternas de economia é um obstáculo ao crescimento e desenvolvimento do progresso capitalista. A ética de extermínio, de que há vidas matáveis sem que fira de morte a legalidade (Foucault, 2008; Mbembe, 2011) e a ética política do Estado se disseminou pelas populações, notadamente nas classes médias e altas, com centelhas entre os operários (Quijano, 1992). Ribeiro procura demonstrar em várias passagens de "O povo brasileiro" essa noção selvática: "O próprio diretor do Museu Paulista e eminente cientista pediu ao governo que optasse entre a selvageria e a civilização. Se seu propósito era civilizar o país, cumpria abrir guerras de extermínio com tropas oficiais para resolver o problema" (1995:147). 


\section{Conclusão}

A vitória parcial de um conceito etnocêntrico de racionalidade política e econômica que ergueu o colonialismo e as noções de tutela no pós colonialismo tomou-se por completa e total, assim como o conceito de modernidade civilizatória que coloca de um lado os 'modernos' e de outro os não desenvolvidos à sua maneira. Santos (2007) chama tal razão de indolente e lhe dá duas características. A primeira, razão metonímica, que toma a parte pelo todo e considera o todo segundo essa parte. Assim, vê no iluminismo e nas ciências desenvolvidas a partir do centro-europeu o espelho do mundo todo e de todo conhecimento. A Segunda é a razão proléptica que sabe o fim, mas o esconde. Pensa que o desenvolvimento do futuro está dado e o caminho é sem retorno, expandindo o presente europeu infinitamente para o futuro do mundo todo.

Não é apenas um conceito comum de universalidade, mas um a priori somado a um imperativo categórico, vinculando o fazer humano em todos os lugares a determinado espaço geográfico que desconhece conhecimentos e economias outras e fazem da parte todo conhecimento, e obriga, sob a força econômica, científica e bélica a todas as pessoas e povos a submeterem-se a sua 'modernidade' capitalista (Quijano, 1992). Essa noção de supremacia e infantilização tutela aos povos descolonizados para que sigam a linearidade imperativa do futuro político-econômico inevitável.

Ao lado do capitalismo dependente, ao qual os independentistas e republicanos aderiram, mantém-se a dificuldade de sua extensão e aprofundamento social, porque junto com as contradições de classes inerentes ao sistema capitalista, com incremento da pobreza, tem-se de lidar com as resistências dos povos originários nas terras que dominam e a crescente organização dos pobres das cidades que, aos poucos, se aproximam do discurso econômico-social daqueles povos, vinculando-se a eles através das lutas ambientais e por subjetividades diversificadas.

Por fim, os vários processos de resistências locais têm perspectivas de horizonte locais e federativos, ou seja, tendência a evoluirem para todo o território americano como complexos movimentos contestadores da colonialidade remanescente e sua forma de organização social, ao que parece, tendente a se firmar no cotidiano das lutas sociais e econômicas por autonomias políticas e multiplas territorialidades locais, como forma de defesa de modos de vida ecologicamente sustentáveis, que se juntam a luta ecológica mundial em um sistema hibrido de anarquismos e municipalismos.

\section{Referências bibliográficas}

ANDERSON, Benedict (1993), Comunidades Imaginadas, México, Fondo de Cultura Economica. BERNAL, Ignacio (2017), Formacion y desarrollo de Mesoamérica, Org. Centro de Estudios Históricos, Historia Geral de México, CD de México, El Colégio de México, p.128-149. 
BHETELL, Leslie (1990), Colonial Latin America, Barcelona, Editorial Crítica.

BRASIL, (2015), Decreto 8.447. http://legislacao.planalto.gov.br/legisla/legislacao.nsf/Viw Identificacao/DEC\%208.447-2015?OpenDocument, Consultado em 03/03/2020

BRASIL (1994), Índios no Brasil, Vários autores: organizado por Luís Donisete Benzi Grupioni, Brasília, MEC.

CARRASCO, Pedro (2017), Cultura y sociedad en el Mexico Antiguo, Org. Centro de Estudios Históricos, Historia Geral de México, CD de México, El Colégio de México, p.153-232.

CUSICANQUI. Silvia R (2010), Violencias (re) encubiertas en Bolívia, La Paz, La mirada selvagem.

FAUSTO, Carlos (2010), Os índios antes do Brasil, Rio de Janeiro, Zahar.

FENNER, Justus (2010), "Los deslindes em el porfiriatoy la estrutura agraria posrevolucionaria". Org. Justus Fenner y Miguel Guillén, La revolucion mexicana en Chiapas un siglo después, México, UNAM, p. 117-158.

FERNANDES, Florestan (1972), Capitalismo Dependente, Rio de Janeiro, Zahar.

FOUCAULT, Michel (2008), Nascimento da biopolítica, São Paulo, Martins Fontes.

FOUCAULT, Michel (2008), Segurança, território, população, São Paulo, Martins Fontes.

FRANK, André G (1980), Acumulação dependente e subdesenvolvimento, São Paulo, Brasiliense.

FURTADO, Celso (2005), Formação Econômica do Brasil, São Paulo, Cia Nacional.

FURTADO, Celso (2013), O Essencial, São Paulo, Cia da Letras.

GALEANO, SupComandante et all (2015). El Pensamiento Crítico Frente a la Hidra Capitalista, Sem editora, Sem lugar.

GARCÍA, Alejandro Cerda (2011), Imaginando zapatismo, Xochimilco, UAM.

IBGE (2012), Censo Demografico 2010, Indígenas, Rio de Janeiro, IBGE.

LINERA, Álvaro (1998), "Narrativa colonial y narrativa comunal". in Memoria de la XI Reunión Anual de Etnología, La Paz, MUSEF, p. 252-53.

LIRA, Andrés y MURO, Luis (2017), El siglo de la integración, Org. Centro de Estudios Históricos, Historia Geral de México, CD de México, El Colégio de México, p.307-360.

LOPES, Reinaldo José (2017), 1499: a pré-história do Brasil, Rio de Janeiro, Harper Collins.

LOURENZO, José Luis (2017), "Los orígenes mexicanos". Org. Centro de Estudios Históricos, Historia Geral de México, CD de México, El Colégio de México, p. 93-122.

LUXEMBURGO, Rosa (1970), A acumulação do capital, Rio de Janeiro, Zahar.

MARTINEZ, Bernardo García (2017), "La creación de Nueva Espanha". Org. Centro de Estudios Históricos, Historia Geral de México, CD de México, El Colégio de México, p. 235-304.

MARX, Karl (1982), Para a crítica da economia política, São Paulo, Abril Cultural, 1982.

MARX, Karl (1964), Formações econômicas pré-capitalistas, São Paulo, Paz e Terra.

MARX, Karl (2008), Contribuição à crítica da economia política, São Paulo, EP.

MORA, Mariana (2018), Política Kuxlejal, CD. México, CIESAS.

ONU. (2016), Brasil: . acesso em 27 de maio de 2018. https://nacoesunidas.org/ situacao-dos-povos-indigenas-no-brasil-e-a-mais-grave-desde-1988-diz-relatora-da-onu/.

OSÓRIO, Jayme (2017), El sistema-mundo de Wallerstein y su trasnformacion, Online. http://marxismoyrevolucion.org/wp-content/uploads/2017/08/sistema_mundo.pdf. Acesso 20/5/2018

PRADO Jr., Caio (1970), História Econômica do Brasil, São Paulo, Brasiliense.

QUIJANO, A. (1992), Colonialidad y modernidad/racionalid, Perú Indígena, 13 (29), 11-20.

RIBEIRO, Darcy (1995), O povo brasileiro, São Paulo, Cia das Letras.

RIBEIRO, Darcy (1996), Os índios e a civilização, São Paulo, Cia da Letras.

RIBEIRO, Fernando B (2017), Uma Sociologia do Desenvolvimento, Famalicão, Húmus.

SANTOS, Boaventura S (2019), "Los modos de producion de ignorancia”. Portugal: In Público. https:// blogs.publico.es/espejos-extranos/2019/03/18/los-modos-de-produccion-de-ignorancia/. 
SANTOS, Boaventura S (2007), Renovar a teoria crítica e reinventar a emancipação social. São Paulo, Boitempo.

SANTOS, Boaventura S (2003), Reconhecer para Libertar: os caminhos do cosmopolitismo multicultural, Rio de janeiro, Civilização Brasileira.

SANTOS, Theotonio (2015), Obras reunidas, CD. México: Obra virtual.

SANTOS, Theotonio (2012), A teoria da dependência e a descoberta do sistema mundo. Online https://americalatinaepolitica.files.wordpress.com/2012/02/dossantos.pdf.

SCHUMPETER, Joseph A (1997), Os Economistas, São Paulo, Nova Cultural.

SIMINERAL (2019), in http://simineral.org.br/mineracao/principais-projetos, acesso em 29 de novembro de 2019.

SENGHOR, Leopold; MADRIDEJOS, Mateo (1979), Teorias sobre o colonialismo, Rio de Janeiro, Salvat.

STEIN, Stanley; BARBARA, H (1970), La herencia colonial de América Latina, México, Siglo XXI.

TODOROV, Tzvetan (1993), A conquista da América, São Paulo, Martins Fontes.

TOLEDO, Ezequiel et FRAGA Julia (2019), El derecho de consulta previa en la transición energética mexicana, Cahiers des Amériques Latines, 90|123-140.

WEBER, Max ( 1979), Ensaios de Sociologia, Rio de Janeiro, LTC. 